\title{
La langue de la bourse : convergences et divergences
}

Catherine Resche

\section{(2) OpenEdition}

\section{Journals}

Édition électronique

URL : http://journals.openedition.org/asp/3747

DOI : 10.4000/asp.3747

ISSN : 2108-6354

\section{Éditeur}

Groupe d'étude et de recherche en anglais de spécialité

\section{Édition imprimée}

Date de publication : 1 décembre 1995

Pagination : 91-112

ISSN : 1246-8185

\section{Référence électronique}

Catherine Resche, "La langue de la bourse : convergences et divergences », ASp [En ligne]

7-10 | 1995, mis en ligne le 19 octobre 2013, consulté le 21 avril 2019. URL : http:// journals.openedition.org/asp/3747 ; DOI : 10.4000/asp.3747

Ce document a été généré automatiquement le 21 avril 2019

Tous droits réservés 


\title{
La langue de la bourse : convergences et divergences
}

\author{
Catherine Resche
}

\section{NOTE DE L'ÉDITEUR}

L'auteur de cette contribution n'a pas autorisé sa publication en ligne.

\section{RÉSUMÉS}

La langue de la bourse, langue de spécialité, est à la fois une langue technique et une langue imagée, empruntant largement à la langue commune, avec des parallélismes frappants en français et en anglais sur le plan des métaphores. La terminologie comparée permet d'établir méthodiquement les convergences et de faire ressortir les divergences et fait le constat des néologismes réussis et des erreurs de la normalisation forcée.

The language of the stock exchange is both a technical language for specific purposes and a metaphorical language that borrows largely from the common language. Strikingly, the metaphors are inspired by the same fields in French and in English. Comparative terminology enables us to take stock of the common points and differences methodically, assessing successful neologisms and sterile attempts at artificially imposing norms. 
INDEX

Keywords : axiom, language of the stock exchange, metaphor, neologism, norm, terminological unit, terminology

Mots-clés : adage, langue de la bourse, métaphore, néologie, norme, terminologie, unité terminologique

\section{AUTEUR}

\section{CATHERINE RESCHE}

Catherine Resche enseigne à l'Université Paris 2 Panthéon-Assas. catherineresche@clubinternet.fr 